\title{
Kajian Usahatani Cabai Merah di Desa Mendalo Indah Kecamatan Jambi Luar Kota Kabupaten Muaro Jambi
}

\section{Research on Red Chili Farming in Mendalo Indah Village, Jambi Luar Kota District, Muaro Jambi Regency}

\author{
Mirawati Yanita ${ }^{1}$, A. Rahman ${ }^{2}$ \\ ${ }^{1,2}$ Program Studi Agribisnis, Fakultas Pertanian, Universitas Jambi
}

\begin{tabular}{l} 
ARTICLE INFO \\
\hline Article history: \\
DOI: \\
10.30595/pspfs.v2i.200 \\
Submitted: \\
July 29,2021 \\
Accepted: \\
Sept 10, 2021 \\
Published: \\
Nov 10, 2021 \\
\hline
\end{tabular}

Keywords:

Red Chili, Cost, Revenue, Income

\begin{abstract}
Red chili is one of the horticultural commodities that are commercially cultivated and become one of the strategic commodities. The commodity is used as a householdfood necessity and a pharmaceutical raw material, although productivity and price often fluctuate. This study aims to (1) Counting the cost and receipt of red chili farming in Mendalo Indah village Jambi district outside the city of Muaro Jambi. (2) Analyzing the large income of red chili farming in Mendalo Indah Village, Jambi District Outside Muaro Jambi Regency. This study used primary data of as many as 50 red chili farmers who were taken deliberately (purposive), considering that only Mendalo Indah Village was conducting sustainable red chili farming activities in the Jambi district outside the city. The method of population retrieval used in this study is by census method. The data analysis method used quantitative analysis. Based on the results of the research obtained that the average total cash cost is $\mathrm{Rp}$ $16,905,304 /$ farmer/MT and $\mathrm{Rp} 23,359,273 / \mathrm{ha} / \mathrm{MT}$ and the unpaid fee (taken into account) is $\mathrm{Rp} 8,255,687 /$ farmer/MT and $\mathrm{Rp} 12,322,293 /$ $\mathrm{ha} / \mathrm{MT}$. The average revenue obtained by farmers is Rp $98,071,560 /$ farmer/MT and Rp.146,294,776/ha/MT. so that the average income amounted to $\mathrm{Rp} 81,166,256 /$ farmer/MT and $\mathrm{Rp}$ $121,143,605 / \mathrm{ha} / \mathrm{MT}$. In the future, farmers are expected to manage agricultural inputs by implementing good agricultural practices to increase productivity further.
\end{abstract}

This work is licensed under a Creative Commons Attribution 4.0 International License.

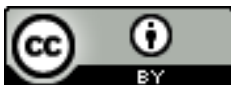

Corresponding Author:

Mirawati Yanita

Program Studi Agribisnis, Fakultas Pertanian, Universitas Jambi

Email: mirawatiyanita@unja.ac.id

\section{PENDAHULUAN}

Sektor pertanian dalam Produk Domestik Bruto (PDB) atas harga konstan menunjukkan pengaruh besar setiap tahunnya dengan peningkatan $15,7 \%$ pada tahun 2014 - tahun 2018. Subsektor tanaman hortikultura pada tahun 2014 - 2018 meningkat sampai dengan 16,7 \%. hal ini menunjukkan bahwa subsektor hortikultura memiliki peran penting dalam mendukung perekonomian nasional (Badan Pusat Statistik Indonesia, 2020).

Cabai merah merupakan salah satu komoditas hortikultura yang diusahakan secara komersial. Cabai merah menjadi salah satu komoditas strategis. Komoditas ini tidak hanya digunakan sebagai kebutuhan pangan rumah tangga tetapi juga sebagai bahan baku farmasi (Indrasti et al., 2021). Cabai merah merupakan produk pangan paling berpengaruh secara ekonomi, dimana kenaikan harga cabai merah dapat berdampak langsung 
pada perekonomian nasional (Yusmaini et al., 2021). Cabai merah juga berkontribusi signifikan bagi perekonomian lokal dan nasional melalui efek penggandanya (Mariyono \& Sumarno, 2015). Cabai merah adalah komoditas yang berkontribusi pada 50 persen dari total konsumsi cabai di Indonesia, (Webb \& Kosasih, 2011).

Provinsi Jambi merupakan, provinsi yang membudidayakan cabai merah dengan hasil produksi tertinggi kedua tahun 2017 (Badan Pusat Statistik Indonesia, 2020) yaitu sebesar 399,241 kwintal. Cabai merah di produksi di seluruh kabupaten atau kota dengan jumlah produksi bervariasi. Kabupaten Muaro Jambi merupakan salah satu daerah sentra penghasil cabai merah dengan peningkatan hasil produksi sebesar 30\% pada tahun 2016. Kecamatan Jambi Luar Kota merupakan salah kecamatan yang berada di Kabupaten Muaro Jambi yang mengusahakan kegiatan usahatani cabai merah dengan rata-rata peningktan hasil produksi pada tahun 2016 - tahun 2017 sebesar 58\%.

Menurut Sistem Informasi Manajemen Penyuluhan Pertanian (2018), di Kecamatan Jambi Luar Kota Desa Mendalo Indah mengusahakan kegiatan usahatani cabai merah. Hasil produksi sangat menentukan jumlah ketersediaan cabai dan besarnya pendapatan petani. Upaya meningkatkan produksi cabai merah di daerah penelitian memerlukan informasi dan usaha. Produktivitas dan harga yang selalu berfluktuasi memerlukan kegiatan penyuluhan kepada petani sebagai sumber informasi untuk menghasilkan dan meningkatkan produksi dengan mempertimbangkan hasil produksi. Hasil produksi sangat mempengaruhi tingkat pendapatan petani, jika semakin tinggi hasil produksi dan semakin bagus kualitas cabai merah, maka diharapkan semakin tinggi juga pendapatan yang diperoleh petani.

\section{METODE PENELITIAN}

\section{Ruang Lingkup Penelitian}

Penelitian ini dilakukan untuk menghitung biaya dan penerimaan usahatani cabai merah. Selain itu juga akan dianalisis pendapatan usahatani cabai merah tersebut Data yang digunakan menggunakan data primer. Penelitian dilaksanakan di Desa Mendalo Indah, Kecamatan Jambi Luar Kota.

\section{Metode Analisis Data}

Metode analisis data yang digunakan adalah metode deskriptif kuantitatif. Data disajikan secara tabulasi yang berasal dari kuesioner terstruktur yang disusun sesuai dengan klasifikasi jenis data. Analisis data digunakan untuk mengetahui besar biaya, penerimaan dan pendapatan usahatani cabai merah di daerah penelitian.

\section{Analisis Pendapatan Usahatani}

Analisis pendapatan digunakan untuk melihat pendapatan pada usahatani kelompok tani cabai merah dengan menghitung penerimaan dan biaya. Adapun cara yang digunakan untuk menghitung penerimaan, yaitu:

$\mathrm{TR}=\mathrm{P} \cdot \mathrm{Q}$

Keterangan:

TR : Penerimaan total (Rp)

Q : Quantity atau jumlah produksi $(\mathrm{kg})$

$\mathrm{P} \quad$ : Price atau harga $(\mathrm{Rp} / \mathrm{kg})$

Dari penerimaan tersebut maka diketahui formula untuk menghitung pendapatan :

$\mathrm{I}=\mathrm{TR}-\mathrm{TC}$

Keterangan:

I $\quad$ : Pendapatan $(\mathrm{Rp})$

TC : Total cost atau total biaya tunai (Rp)

Menghitung penyusutan alat dalam penelitian ini digunakan metode percentage dari harga pembelian, yaitu metode penyusutan (depresiasi) yang paling sederhana dan banyak digunakan ntuk menghitung biaya penyusutan alat, dengan metode persentase dari harga pembelian digunakan rumus sebagai berikut:

$\mathrm{Pa}=\frac{\mathrm{Np}-\mathrm{Ns}}{n \times N}$

Keterangan:

$\mathrm{Pa} \quad$ : penyusutan alat $(\mathrm{Rp})$

$\mathrm{Np} \quad$ : harga beli $(\mathrm{Rp})$

Ns : nilai Sisa $(\mathrm{Rp})$

n : taksiran umur kegunaan (tahun)

$\mathrm{N} \quad$ : jumlah barang 
Metode persentase dari harga pembelian dikemukakan oleh Manulang (2008), dalam metode ini jumlah penyusutan setiap tahunnya sama dengan harga pembelian dari barang modal dikurangi dengan nilai sisa dibagi umur ekonomis dari barang yang bersangkutan.

\section{HASIL DAN PEMBAHASAN}

\section{Biaya Usahatani Cabai Merah}

Biaya usahatani tergolong pada biaya tetap dan biaya variabel. Biaya tetap adalah biaya yang penggunaannya tidak habis satu kali proses produksi. Kegiatan usahatani cabai merah yang termasuk dalam biaya tetap adalah biaya penyusutan alat dan sewa lahan pada usahatani cabai merah di daerah penelitian sedangkan yang dimaksud biaya variabel adalah biaya benih, pupuk KCl, pupuk NPK, pupuk kandang, obatobatan, tenaga kerja luar keluarga, tenaga kerja dalam keluarga dan biaya sewa alat. Biaya tetap dan biaya variabel pada usahatani cabai merah meghasilkan biaya total usahatani cabai merah di daerah penelitian.

Tabel 1. Rata-rata Biaya Produksi Usahatani Cabai Merah di Daerah Penelitian

\begin{tabular}{lrc}
\hline \multicolumn{1}{c}{ Komponen Biaya } & $\begin{array}{c}\text { Per Petani } \\
\text { (Rp/MT) }\end{array}$ & $\begin{array}{c}\text { Per Ha } \\
\text { (Rp/MT) }\end{array}$ \\
\hline Biaya Tetap (FC) & & 45.895 \\
\hline Cangkul & 30.750 & 53.216 \\
Sabit & 35.655 & 29.402 \\
Sprayer & 19.700 & 116.477 \\
Mesin Air & 78.040 & 4.965 .671 \\
Sewa Lahan & 3.327 .000 & \\
\hline Biaya Variabel (VC) & & 2.498 .627 \\
\hline Benih & 1.674 .080 & 3.974 .447 \\
Pupuk & 2.662 .880 & 244.993 \\
Obat-obatan & 164.145 & 4.699 .429 \\
Mulsa & 3.127 .000 & 13.751 .045 \\
TKLK & 9.213 .200 & 7.089 .925 \\
TKDK & 4.750 .250 & 94.680 \\
Sewa Alat & 63.000 & \\
\hline
\end{tabular}

Tabel 1 menjelaskan penggunaan biaya tertinggi yang dikeluarkan petani yaitu biaya tenaga kerja luar keluarga sebesar Rp 9.213.200petani/MT dan Rp 13.751.045/ha/MT atau sebesar 25 persen, sedangkan biaya terendah adalah biaya tetap sabit yaitu Rp 17.462/petani/MT dan Rp 26.331/ha/MT atau sebesar 0,09 persen.

\section{Penerimaan Usahatani}

Penerimaan usahatani merupakan nilai yang diperoleh dari total produksi usahatani yang dikelola oleh petani responden di daerah penelitian. Penerimaan hasil penjualan produksi disebut juga sebagai pendapatan kotor karena belum dikurangi dengan biaya-biaya yang dikeluarkan pada usahatani cabai merah. Nilai penerimaan yang diperoleh petani merupakan nilai dari perhitungan hasil panen dari seluruh petani responden yang dikalikan dengan harga jual cabai merah.

Tabel 2. Rata-rata Produksi, Harga dan Penerimaan Usahatani Cabai Merah di Daerah Penelitian

\begin{tabular}{lc}
\hline Keterangan & Jumlah \\
\hline Produksi (kg) & 9.335 \\
Harga (Rp./kg) & 10.500 \\
Penerimaan per petani (Rp./MT) & 98.071 .500 \\
Penerimaan per ha (Rp./MT) & 146.294 .776 \\
\hline
\end{tabular}

Berdasarkan Tabel 2, menunjukkan bahwa dengan produksi sebesar 9.335 Kilogram pada saat harga setiap kilogram sebesar Rp 10.500, diperoleh penerimaan sebesar Rp.146.294.776. Faktor penting dalam hal kegiatan usahatani adalah pasar dan harga. Harga cabai merah biasa berfluktuasi. Umumnya, jika produksi melimpah, maka harga akan menurun dan para petani cenderung mengalami kerugian. Selain itu, inefisiensi pemasaran 
rantai pasokan yang lebih panjang berkontribusi terhadap keuntungan yang relatif kecil bagi petani (Puspitawati dan Wardhani, 2013).

Analisis Pendapatan

Tabel 3. Analisis Pendapatan Usahatani Cabai Merah di Daerah Peneltian

\begin{tabular}{|c|c|c|c|c|c|}
\hline Uraian & Jumlah & $\begin{array}{c}\text { Harga } \\
\text { (Rp) }\end{array}$ & $\begin{array}{c}\text { Per Petani } \\
\text { (Rp/MT) }\end{array}$ & $\begin{array}{c}\text { Per Ha } \\
\text { (Rp/MT) }\end{array}$ & $\begin{array}{c}\text { Persen } \\
(\%)\end{array}$ \\
\hline \multicolumn{6}{|l|}{ A. Penerimaan } \\
\hline - Produksi (kg) & 9.335 & 10.500 & 98.071 .560 & 146.294 .776 & \\
\hline \multicolumn{6}{|l|}{ B. Biaya yang Tunai } \\
\hline Benih (gr) & 209,26 & 8.000 & 1.674 .080 & 2.498 .627 & 7,0 \\
\hline Pupuk KCl (kg) & 140 & 8.000 & 1.118 .880 & 1.669 .970 & 1,38 \\
\hline Pupuk NPK (kg) & 79,9 & 10.000 & 799.999 & 1.192 .537 & 3,32 \\
\hline Pupuk Kandang (kg) & 745 & 1.000 & 745.000 & 1.111 .940 & 3,10 \\
\hline \multicolumn{6}{|l|}{ Obat-obatan (1) } \\
\hline - Regent 50 CC & 0,1025 & 300.000 & 30.750 & 45.896 & 0,13 \\
\hline - Curacron 500 EC & 0,24 & 150.000 & 35.655 & 53.216 & 0,15 \\
\hline - Trensida & 0,14 & 200.000 & 19.700 & 29.403 & 0,08 \\
\hline - Explore 250 EC & 0,2 & 400.000 & 78.040 & 116.478 & 0,32 \\
\hline Mulsa (m) & 625,4 & 5.000 & 3.127 .000 & 4.699 .429 & 13,08 \\
\hline TKLK (HOK) & 92,12 & 100.000 & 9.213 .200 & 13.751 .045 & 38,29 \\
\hline Sewa Alat (Rp) & & & 63.000 & 94.030 & 0,26 \\
\hline Total Biaya Tunai & & & 16.905.304 & 23.594 .273 & \\
\hline \multicolumn{6}{|c|}{ C. Biaya yang Diperhitungkan } \\
\hline Biaya Penyusutan Alat & & & 178.687 & 266.697 & 0,74 \\
\hline Sewa Lahan & & & 3.327 .000 & 4.965 .671 & 13,83 \\
\hline TKDK & 47,5 & 100.000 & 4.750 .000 & 7.089 .955 & 19,74 \\
\hline \multicolumn{3}{|c|}{ Total Biaya yang Diperhitungkan } & 8.255.687 & 12.322 .293 & \\
\hline \multicolumn{3}{|l|}{ D. Total Biaya $(B+C)$} & 25.161.241 & 35.916 .566 & \\
\hline \multicolumn{3}{|l|}{ E. Pendapatan (A-B) } & 81.166 .256 & 121.143.665 & \\
\hline
\end{tabular}

Berdasarkan tabel diatas menjelaskan bahwa rata-rata pendapatan yang diperoleh petani di daerah penelitian sebesar Rp 81.166.256/petani/MT dan Rp 121.143.665/ha/MT. Total pendapatan ini hampir mendekati pendapatan yang diperoleh petani cabai merah di Kecamatan Ciawi Kabupaten Bogor yaitu sebesar Rp 146.537.533/ha/MT dengan rata-rata hasil produksi sebesar 8,374 ton/ha, total biaya tunai yang dikeluarkan sebesar Rp 55.401.539/ha/MT dengan biaya tertingi yang dikeluarkan adalah biaya penggunaan tenaga kerja luar keluarga yaitu Rp 30.247.170/ha/MT atau sebesar 50,69\% dari total biaya yang dikeluarkan sehingga petani cabai merah di Kecamatan Ciawi Kabupaten Bogor memperoleh pendapatan sebesar Rp 91.135.995/ha/MT (Siregar, 2011). Tetapi angka ini masih lebih kecil dibandingkan dengan pendapatan petani cabai merah di Kabupaten Lamongan (Hamidah, 2016).

\section{KESIMPULAN}

Berdasarkan hasil penelitian Produksi dan Pendapatan Usahatan Cabai Merah di Desa Mendalo Indah Kecamatan Jambi Luar Kota Kabupaten Muaro Jambi yang telah dilaksanakan, maka dapat ditarik kesimpulan. Rata-rata total biaya tunai yang dikeluarkan petani usahatani cabai merah di Desa Mendalo Indah Kecamatan Jambi Luar Kota Kabupaten Muaro Jambi adalah Rp.16.905.304/ petani/MT dan Rp.23.594.273/ha/MT. Ratarata penerimaan yang di peroleh adalah Rp.98.071.560/petani/MT dan Rp.146.294.776/ha/MT. Berdasarkan hasil penelitian diperoleh rata-rata pendapatan usahatani cabai merah di daerah penelitian sebesar Rp.81.166.256/petani/MT dan Rp.121.143.665/ha/MT. 


\section{DAFTAR PUSTAKA}

Badan Pusat Statistik Indonesia. (2020). Statistik Hortikultura. Direktorat Diseminasi Statistik. https://doi.org/10.21608/jkom.2020.120332.

Hamidah, E. (2016). Analisis Pendapatan Usahatani Cabai Merah. Journal Saintis, 8(2), 113-126.

Indrasti, R., Rawung, J. B. M., Sudolar, N. R., Andri, K. B., Tan, S. and, \& Tan, S. S. (2021). Farmer institutional and economic feasibility study on red chilli pepper farming in Kepung District , Kediri Regency , East Java Province Farmer institutional and economic feasibility study on red chilli pepper farming in Kepung District, Kediri Regency. IOP Conf. Series: Earth and Environmental Science 807 (2021) 022018. https://doi.org/10.1088/1755-1315/807/2/022018.

Mariyono, J., \& Sumarno, S. (2015). Journal of Agribusiness in Developing and Emerging Economies. Chilli Production and Adoption of Chilli-Based Agribusiness in Indonesia, 5(1), 57-75. https://doi.org/Doi.org/10.1108/ JADEE-01-2014-0002.

Puspitawati I R and Wardhani R M. (2013). Analisa efisiensi pemasaran komoditi cabai pada beberapa saluran pemasaran di Kota Madiun. Jurnal Agri-Tek, 14(1), 72-86.

Siregar, N. (2011). Analisisi Pendapatan Usahatani dan Faktor-Faktor yang Mempengaruhi Produksi Cabai Merah Keriting di Desa Citapen Kecamatan Ciawi Kabupaten Bogor. Institut Pertanian Bogor.

Webb, A. J., \& Kosasih, I. A. (2011). Analysis of Price Volatility in the Indonesia Fresh Chili Market The authors welcome comments and suggestions. Please address them to : awebb@aswebb.com Analysis of Price Volatility in the Indonesia Fresh Chili Market. The Annual Meeting of the International Agricultural Trade Research Consortium, .

Yusmaini, Usman, R., Safrida, \& Kasimin, S. (2021). No Title. IOP Conf. Series: Earth and Environmental Science 644 (2021) 012066 Doi:10.1088/1755-1315/644/1/012066, 1-9. 